\title{
Scenedesmus sp.'nin DPPH (1,1-difenil-2-pikrilhidrazil) Serbest Radikal Süpürücü Aktivitesi
}

\author{
Elif Neyran SOYLU ${ }^{*}$, Ayşegül ÇEBİ \\ ${ }^{1}$ Giresun Üniversitesi, Fen Edebiyat Fakültesi, Biyoloji Bölümü, Giresun, TÜRKIYE \\ ${ }^{2}$ Giresun Üniversitesi, Mühendislik Fakültesi, Gıda Mühendisliği Bölümü, Giresun, TÜRKIYY
}

"Sorumlu Yazar: cebiaysegul@hotmail.com

Geliş Tarihi: 15.11.2017

Kabul Tarihi: 08.12.2017

\section{Özet}

Giresun ili derelerinden izole edilen ve kültür şartları altında BG11 besi yerinde yetiştirilen Scenedesmus sp. türünün DPPH (1,1-difenil-2-pikrilhidrazil) serbest radikal süpürücü aktivite tayini için spektrofotometrik DPPH yöntemi kullanılmıştır. 10-3 M DPPH etanol çözeltisinden $1 \mathrm{~mL}$ alınıp $3 \mathrm{~mL}$ ekstrakt çözeltisi ilave edilip vorteks ile çalkalanmıştır. 30 dakika karanlıkta bekletilip $517 \mathrm{~nm}$ 'de absorbans okunmuştur. Standart antioksidan olarak BHT ve Troloks kullanılmıştır. DPPH radikalini süpürme aktivitesi formül kullanılarak hesaplanmıştır.

Anahtar Kelimeler: Scenedesmus sp., DPPH, alg kültür ekstraksiyonu.

\section{DPPH (1,1-diphenyl-2-picrylhydrazyl) Free Radical Sweeping Activity of Scenedesmus sp.}

\begin{abstract}
Spectrophotometric DPPH method was used for the determination of DPPH (1,1-diphenyl-2-picrylhydrazyl) free radical scavenging activity of Scenedesmus sp. which was isolated from the Giresun mine and cultivated under BG11 culture conditions. $1 \mathrm{~mL}$ of 10-3 M DPPH ethanol solution was added and $3 \mathrm{~mL}$ of extract solution was added and vortexed. The absorbance was read at $517 \mathrm{~nm}$ for 30 minutes in the dark. BHT and Trolox were used as standard antioxidants. The DPPH radical scavenging activity reaction was calculated using the formula.
\end{abstract}

Keywords: Scenedesmus sp, DPPH, algae culture extraction. 


\section{Giriş}

Mikroalgler aquatik ekosistemlerde besin zincirinin ilk halkasını oluştururlar. Güneş enerjisinin yardımıyla $\mathrm{H} 2 \mathrm{O}$ ve CO2'yi kullanarak kompleks organik bileşikler sentezleyip bir çok primer ve sekonder metabolitler salgilar ve/veya biriktirirler (Guedes ve ark., 2011; Tandeau-de-Marsac ve Houmard, 1993; Leon ve ark., 2003). Bunun yanında mikroalgler oksidatif strese hem enzimatik hem de enzimatik olmayan mekanizmalar içeren antioksidan savunma sistemlerinin stimulasyonu yoluyla adaptif tepkiler gösterirler (Srivastava ve ark., 2003).

Algler yapısında birçok biyoaktif bileşen bulundurduklarından doğada bulunan biyolojik aktivitesi en yüksek kaynaklardandır. Alglerin protein, aminoasit, vitamin ve çeşitli mineral maddeler yönünden zengin olduğu bu nedenle de kullanım alanının geniş olduğu bilinmektedir (El-Sheekh ve ark., 2006). Algler sahip oldukları bu yüksek değerlikli bileşikler sayesinde gıda ham maddesi veya katkı maddesi olarak, kozmetik ve eczacılık gibi ticari alanlarda kullanılmaktadırlar (Akyıl ve ark., 2016).

Diğer taraftan, algler bünyesindeki doğal antioksidanlar sayesinde zengin bir kaynak olarak da görülmektedir (Ngo ve ark., 2010). Alglerde bulunan karotenoidler güçlü biyolojik antioksidanlardır (Guedes ve ark., 2011). Antioksidan eksikliği kanser, kalp ve damar hastalığı, hipertansiyon, şeker hastalığı ve yaşlanma gibi birçok ciddi sağlık sorunlarına neden olmaktadır. Antioksidanlar araştırmacılar tarafından diyet takviyeleri için de bir kaynak olarak düşünülmektedir. Bu çalışmada kültür şartları altında yetiştirilen Scenedesmus sp.'nin DPPH (1,1-difenil-2-pikrilhidrazil) serbest radikal süpürücü aktivitesi araştırılmıştır.

\section{Materyal ve Metot}

\subsection{Kültür Şartları}

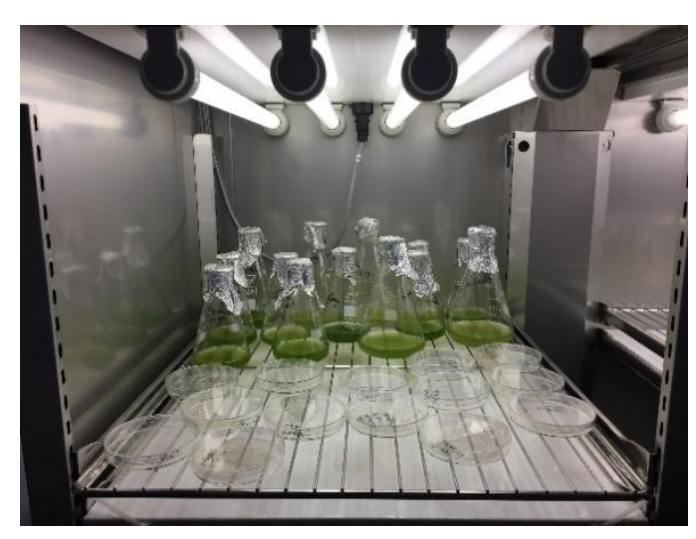

Şekil 1. Scenedesmus sp. türünün kültür şartlarında yetiştirilmesi. 
Kültürler hazırlanan BG11 besi yerlerinde petri kabında veya havalandırılan süspansiyonlarda oda sıcaklığında 12 saat karanlık, 12 saat aydınlık döngüde geliştirilmiştir. Aydınlanma için soğuk florasan lambalar (100 $\mu$ mol foton) kullanılmıştır.

\subsection{Scenedesmus sp'nin Ekstraksiyonu}

Alg kültürünü yetiştiği ortamdan alarak $4000 \mathrm{rpm}$ de $5 \mathrm{dk}$ santrifüj yapıldı. Pellet alındı ve 90 $\mathrm{dk}$ sonikasyona tabi tutuldu. Sonikasyon işleminden sonra -80 derecede 24 saat dondurup sonrasında çözdürüldü. Tekrar $4000 \mathrm{rpm}$ de $5 \mathrm{dk}$ santrifüj edildi. Süpernatant uzaklaştırıldı. Pellet alınıp aseton, etil alkol, metanol (1:1:1) ile karıştırılarak etüvde uçuruldu. Ekstrakt kazınarak elde edildi. Elde edilen ekstrakt çeşitli konsantrasyonlarda dilüe edilerek ölçüme hazır hale getirildi (Wilthire et al., 2000).

\subsection{DPPH (1,1-Difenil 2-Pikril Hidrazil) Serbest Radikal Süpürücü Aktivite Ölçümü}

DPPH ölçümü için, $1 \mathrm{ml}$ 10-3 M DPPH etanol çözeltisi ve $3 \mathrm{ml}$ ekstrakt vorteks ile karıştırıldı. Karanlıkta 30 dakika bekletildikten sonra, absorbansı 517 nm'de okundu. Standart antioksidanlar olarak BHT ve Troloks kullanıldı. DPPH radikalini süpürme aktivitesi reaksiyonu inhibe etme yüzdesi şeklinde ifade edilmek üzere aşağıdaki formül kullanılarak hesaplandı (Brand-Williams ve ark., 1995).

$\%$ İnhibisyon $=[\mathrm{AK}-\mathrm{AÖ} / \mathrm{AK}] \times 100$

AÖ; Antioksidan ihtiva eden örneğin absorbansı

AK: Kontrol (Antioksidan ihtiva etmeyen) absorbansı

\section{Bulgular ve Tartışma}

Mikroalg türleri, Guedes ve ark. (2011) tarafından yapılan daha önceki çalışmalarda da tercih edilmiştir. Bu araştırıcılar Sc. obliquus (M2-1 suşu)'un interselular ekstraktlarının diğer Scenedesmus dizinleri ile karşılaştırıldığında daha yüksek antioksidan kapasiteye sahip olduğunu bulmuşlardır. Ayrıca, organizmanın sahip olduğu radikal süpürücü aktivitenin yüksek olması DNA'da meydana gelen oksidatif hasara karşı koruyucu etkisi ile doğru orantılıdır. 


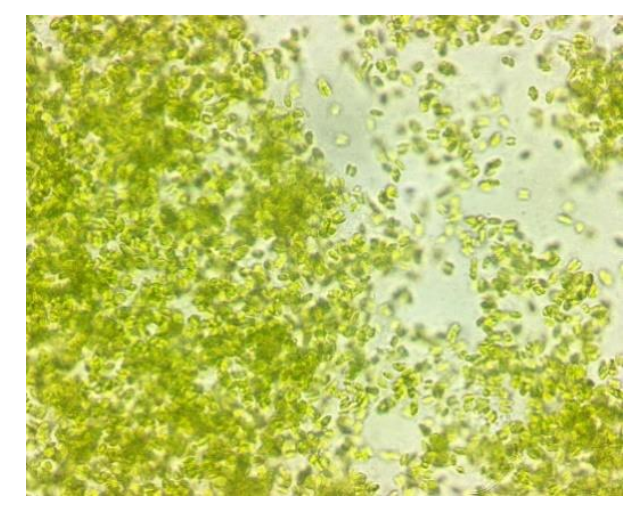

Şekil 2. Ekstraksiyonu yapılmış olan Scenedesmus sp. türünün mikroskobik görüntüsü.

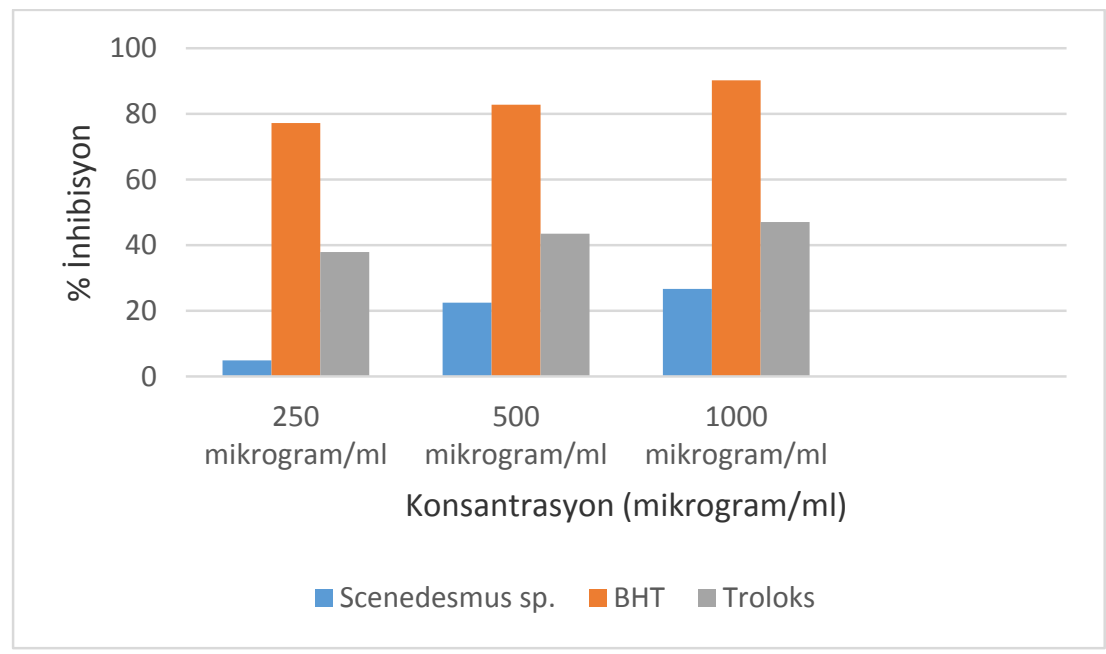

Şekil 3. Scenedesmus sp., BHT ve troloksun \% inhibisyon grafiği.

Prokaryotik ve ökaryotik mikroalglerin lipofilik ve hidrofilik yapılarında antioksidan kapasitesinin değerlendirilmesi üzerine çok sayıda çalışma vardır (Britton, 1995; Herrero ve ark., 2006; Mendiola ve ark., 2007), fakat çoğunun lipidce zengin ekstraktlarda antioksidan süpürücü tahlilleri gerçekleştirilmemiştir. Mikroalglerden önemli ve en iyi bilinen antioksidanlar karotenoidlerdir ve zaten ticari ölçekte ek besin ve yiyecek olarak kullanılmak üzere bunların yanısıra kozmetikte ve besin takviyeleri olarak üretilmektedir (Pulz ve ark., 1995). Bir ekstraktta bulunan bileşikler arasında sinerjik veya antagonik ilişkiler dikkate alınmalıdır.

DPPH antiradikal/antioksidan kapasiteleri belirlemek için geniş ölçüde kullanılmaktadır. DPPH renk girişiminden muzdarip olabilir örneğin karotenoidler veya antosiyaninler durumunda olduğu gibi antioksidan kapasitenin azalmasına yol açabilir. Bundan başka, bu metodun zaman içerisinde fenolik antioksidanlara karşı daha hassas olabileceği rapor edilmiştir (Halim ve ark., 2012; Shalaby ve ark., 2013). Mueller ve ark. (2011) tarafından hazırlanan bir raporda karotenoidlerin antioksidan kapasitesinin değerlendirilmek için birçok metod karşılaştırılmış ve DPPH süpürücü kapasite göstermemiştir. Bununla beraber, bu metod doymamış yağ asitlerinin antioksidan kapasitesini ölçmek için uygun görünmektedir (Fagali ve Catalá, 2008). 
Scenedesmus sp. kültürlerinden yapılan ekstraksiyon sonucu elde edilen 250, 500 ve 1000 mikrogram/ml lik konsantrasyonlardaki alg örneklerinin DPPH aktivitesi için yüzde inhibisyon değerleri sırasıyla 4,91; 22,45 ve 26,66 olarak hesaplanmıştır. Standart antioksidan olarak bilinen BHT ise aynı konsantrasyonlarda sırasıyla 77,19; 82,80 ve 90,17 yüzde inhibisyon göstermiştir. Diğer bir standart antioksidan olan troloks ise yine aynı konsantrasyonlarda sirasıyla 37,89; 43,50 ve 47,01 olarak yüzde inhibisyon göstermiştir.

\section{Sonuçlar ve Öneriler}

Scenedesmus sp. kültürlerinden elde edilen ekstraktın serbest radikal süpürücü aktivitesi standart antioksidanlara göre daha düşük bulunmuştur. Bunun nedeni olarak alg kültürlerindeki yaşam siklusuna göre Scenedesmus sp.'nin en aktif olduğunu döneme denk gelememiş olması düşünülebilir. Scenedesmus sp.'nin radikal süpürücü etki gösterecek olan biyoaktif moleküllerini sentezlediği ve en verimli olduğu dönem tespit edilerek daha ileri çalışmalar yapılması gerekmektedir. Ayrıca farklı çözücüler kullanılarak ve daha ileri ekstraksiyon teknikleri denenerek daha ileri çalışmalara ihtiyaç vardır.

\section{Kaynaklar}

Akyıl, S., İlter, I., Koç, M. ve Kaymak-Ertekin, F., (2016). Alglerden elde edilen yüksek değerlikli biyoaktif/Biyolojik Uygulama Alanları. Akademik Glda, 14 (4), 418-423.

Brand-Williams, W., Cuvelier, M. E. and Berset, C., (1994). Use of free radical method to evaluate antioxidant activity. Lebensmittel-Wissenschaft \& Technologie, 28, 25-30.

Britton, G. (1995). Structure and properties of carotenoids in relation of function. FASEB J., 9,1551-1558.

El-Sheekh, M. M., Osman, M. E. H., Dyab, M. A. and Amer, M. S., (2006). Production and characterization of antimicrobial active substance from the Cyanobacterium Nostoc muscorum. Environmental Toxicology and Pharmacology, 21(1), 42-50.

Fagali, N., and Catalá, A., (2008). Antioxidant activity of conjugated linoleic acid isomers, linoleic acid and its methyl ester determined by photoemission and DPPH radical dot techniques. Biophys. Chem., 137, $56-62$.

Guedes, A., Amaro, H. M., and Malcata, F. X., (2011). Microalgae as sources of high added-value compounds a brief review of recent work. Biotechnology Progress, 27(3), 597-613.

Halim, R., Danquah, M. K., and Webley, P. A., (2012). Extraction of oil from microalgae for biodiesel production: A review. Biotechnol. Adv., 30, 709-732.

Herrero, M., Cifuentes, A., and Ibañez, E., (2006). Sub- and supercritical fluid extraction of functional ingredients from different natural sources: Plants, food by-products, algae and microalgae, A review. Food Chem., 98, 136-148.

Tandeau-de-Marsac, N., and Houmard, J., (1993). Adaptation of cyanobacteria to environmental stimuli: New steps towards molecular mechanisms. FEMS Microbiol. Rev., 104, 119-190.

León, R., Martín, M., Vigara, J., Vilchez, C., and Vega, J., (2003). Microalgae-mediated photoproduction of $\beta$-carotene in aqueous organic two-phase systems. Biomol. Eng., 20, 177-182.

Mendiola, J. A., Jaime, L., Santoyo, S., Reglero, G., Cifuentes, A., Ibañez, E., and Señoráns, F. J., (2007). Screening of functional compounds in supercritical fluid extracts from Spirulina platensis. Food Chem., $102,1357-1367$. 
Mueller, L., and Boehm, V., (2011). Antioxidant Activity of $\beta$-Carotene Compounds in Different in vitro Assays. Molecules, 16, 1055-1069.

Ngo, D. H., Wijesekara, I., Vo, T. S., Van, Q., Ta, S., and Kim, K., (2010). Marine food-derived functional ingredients as potential antioxidants in the food industry: An overview. Food Research International, 44, 523-529.

Shalaby, E. A., and Shanab, S. M. M., (2013). Comparison of DPPH and ABTS assays for determining antioxidant potential of water and methanol extracts of Spirulina platensis. Indian J. Geo-Mar. Sci., 42, 556-564.

Srivastava, A., Bhargava, P., and Rai, L., (2005). Salinity and copper-induced oxidative damage and changes in the antioxidative defense systems of Anabaena doliolum. World J. Microbiol. Biotechnol., 21, 12911298.

Pulz, O., Gerbsch, N., and Bacholz, R., (1995). Light energy supply in plate-type and light diffusing optical fiber bioreactors. J. Appl. Phycol., 7, 145-149.

Wiltshire, K. H., Boersma, M., Möller, A., and Buhtz, H., (2000). Extraction of pigments and fatty acids from the green alga Scenedesmus obliquus (Chlorophyceae). Aquatic Ecology, 34, 119-126. 